\title{
Pengaruh proses blanching dan penambahan karagenan pada kualitas selai lembaran belimbing wuluh (Averrhoa bilimbi L.)
}

\author{
The effect of the blanching process and the addition of carrageenan on the quality of \\ starfruit jam (Averrhoa bilimbi L.)
}

\author{
Devi Rahmah Fauzi ${ }^{1)}$, Hapsari Titi Palupi ${ }^{\left.{ }^{*}\right)}$ \\ ${ }^{1}$ Prodi Ilmu dan Teknologi Pangan, Universitas Yudharta Pasuruan, Jawa Timur. \\ *Email: hapsari76@gmail.com
}

Informasi artikel

Diterima: 08/08/2020; ditinjau: 08/08/2020; disetujui: 01/09/2020

\begin{abstract}
Belimbing wuluh (Averrhoa bilimbi L.) is one of the fruit plants native to Indonesia. Processing of Belimbing wuluh into slice jam is necessary in order to have extended shelf life and to give added value of the se fruit. This study aims to determine the effect of blanching and concentration of carrageenan on the quality of belimbing wuluh sheet jam. The method of this research was a randomized block design (RBD) consisting of 2 factors. The first factor were Blanching, $(B 1)=$ With Blanching, $(B 2)=$ Without Blanching. The second factor were the concentration of carrageenan, carrageenan (K1) $=5 \% . K 2=10 \% . K 3=15 \%$. The result swere analyzed by performed ANOVA using Minitab18 software and continued by the Tukey test. Tthe best treatment was analyzed using the De Garmo Effectiveness Index method. The best treatments found in the B2K2 treatment (without blanching and concentration of carrageenan 10\%.) has an average of water content 19.68\%; vitamin C $14.51 \mathrm{mg} / \mathrm{g}$; texture $0.50 \mathrm{~N} / \mathrm{mm}^{2}$; color L 35.50; $a^{*}$ 13.20; $b^{*}$ 20.80; (organoleptic) texture 3,40 (like); color 3,33 (like); taste 3,47(like); and flavor 3.30 (like).
\end{abstract}

Keywords: Averrhoa blimbi L., sheet jam, blanching, carrageenan

\begin{abstract}
ABSTRAK
Belimbing wuluh (Averrhoa bilimbi L.) merupakan salah satu tanaman buah asli Indonesia. Pengolahan belimbing wuluh menjadi selai lembaran diperlukan untuk memperpanjang masa simpan dan memberi nilai tambah. Penelitian ini bertujuan untuk mengetahui pengaruh blanching dan konsentrasi karagenan pada kualitas selai lembaran belimbing wuluh. Rancangan percobaan adalah rancangan acak kelompok (RAK) yang terdiri dari 2 faktor. Faktor pertama yaitu blanching, $(\mathrm{B} 1)=$ blanching, $(\mathrm{B} 2)=$ Tanpa blanching. Faktor kedua yaitu konsentrasi karagenan, karagenan $(\mathrm{K} 1)=5 \%$. K2 $=10 \%$. $\mathrm{K} 3=15 \%$. Data hasil pengamatan dianalisis anova menggunakan sofware Minitab 18 dengan selang kepercayaan 5\%. Penentuan perlakuan terbaik menggunakan metode Indeks Efektifitas De Garmo. Hasil perhitungan menunjukkan perlakuan terbaik pada perlakuan B2K2 (tanpa blanching dan karagenan 10\%) dengan hasil kadar air 19,68\%; vitamin C 14,51 mg/g; tekstur (fisik) $0,50 \mathrm{~N} / \mathrm{mm}^{2}$; warna L 35,50(a* 13,20; b* 20,80; kesukaan tekstur 3,40 (suka); warna 3,33 (suka); rasa 3,47 (suka) dan aroma 3,30 (suka).
\end{abstract}

Kata Kunci: Averrhoa blimbi L., blanching, karagenan, selai lembaran. 


\section{PENDAHULUAN}

Belimbing wuluh (Averrhoa bilimbi Linn.) merupakan salah satu tanaman buah asli Indonesia, banyak ditemui sebagai tanaman pekarangan yang mudah ditanam dan tidak memerlukan perawatan khusus. Buah belimbing wuluh bergerombol pada tangkainya, memiliki rasa buah yang asam tetapi segar serta mengandung air yang banyak (Dewi, 2009). Belimbing wuluh memiliki antioksidan yang tinggi sehingga berpotensi digunakan sebagai produk makanan kesehatan. Kandungan vitamin C alami sebesar $25 \mathrm{mg} / 100 \mathrm{~g}$ yang berguna sebagai penambah daya tahan tubuh dari perlindungan terhadap berbagai penyakit (Prastian, 2008). Berdasarkan studi, belimbing wuluh merupakan buah yang kurang dimanfaatkan, digunakan dalam masakan lokal sebagai penyedap makanan dan jarang dikonsumsi mentah karena keasaman-nya yang tinggi (Ikram et al., 2009). Buah belimbing juga memiliki umur simpan pendek sekitar 4-5 hari setelah panen, mudah melunak dan mudah rusak apabila buah terluka (Masilungan dan Absulio, 2012). Mengolah belimbing wuluh menjadi selai adalah pilihan yang lebih baik untuk mengawetkan buah dan mendapatkan manfaat kesehatan (Anuar dan Salleh, 2017).

Selai adalah salah satu produk olahan buah berdasarkan prinsip kandungan padatan-asam yang tinggi. Sifat selai adalah memiliki rasa enak yang berasal dari buahbuahan, mengandung komponen gizi yang baik serta memiliki masa simpan yang panjang. Kandungan gula yang tinggi dan $\mathrm{pH}$ rendah merupakan kondisi lingkungan yang tidak disukai oleh mikroba (Kanwal et al., 2017). Selai lembaran merupakan selai yang berbentuk seperti lembaran yang sesuai dengan permukaan roti, tidak cair atau tidak terlalu lembek dan tidak terlalu kaku. Untuk membuat gel pada selai lembaran diperlukan bahan tambahan berupa bahan yang bersifat hidrokoloid yang berfungsi sebagai penguat tekstur selai lembaran. Hidrokoloid yang dapat digunakan untuk penguat tekstur selai lembaran salah satunya adalah karagenan. Karagenan mampu mengendalikan kandungan air pada selai lembaran sehingga tekstur selai lembaran menjadi bentuk lembaran yang kuat dan plastis (Harun, 2016). Selain bersifat hidrofilik, karagenan lebih stabil dalam meng-imobilisasi air pada konsentrasi yang lebih rendahserta mampu membentuk gel yang lebih kuat (Sidi et al., 2014).

Perlakuan pendahuluan blanching pada pengolahan buah bertujuan menginaktifkan beberapa jenis enzim yaitu polyphenoloxidase, peroksidase dan phenolase serta dapat menghambat beberapa reaksi kimia yang tidak diinginkan yang menyebabkan banyak perubahan yang merugikan dari suatu produk. Selain itu blanching dapat mengurangi jumlah kontaminasi mikroorganisme pada permukaan bahan pangan, dan menghilangkan udara yang berada dalam rongga-rongga antar sel jaringan bahan pangan (Yusuf et al., 2016). Penelitian ini bertujuan untuk mengetahui pengaruh proses blanching dan konsentrasi karagenan terhadap karakteristik fisik kimia dan organoleptik selai lembaran belimbing wuluh untuk meningkatkan daya guna dan nilai ekonomis dari belimbing wuluh.

\section{METODE}

\section{Bahan}

Bahan baku yang digunakan yaitu belimbing wuluh, yang berasal dari Desa Durensewu Kecamatan Pandaan Kabupaten Pasuruan, karagenan (Merk Gunung Putri Jawa Barat), glukosa cair, gula pasir (Gulaku), dan tepung agar-agar yang diperoleh dari Toko Bahan Makanan.

Bahan untuk analisis adalah aquades, buffer $\mathrm{pH} 4$ dan 7, amilum 1\%, yodium $0.001 \mathrm{~N}$, larutan $\mathrm{NaOH} 0.1 \%$, etanol $95 \%$,.

\section{Alat}

Alat yang digunakan untuk membuat produk yaitu kompor gas, wajan, panci dan baskom stainless steel, blender, saringan, pisau, timbangan kue, aluminium foil, dan loyang. Peralatan untuk analisis antara lain, 
timbangan analitik, kertas saring, cawan petri, erlenmeyer, labu takar, pipet tetes, pipet volum, color reader, dan penetrometer.

\section{Rancangan percobaan}

Rancangan percobaan yang digunakan dalam penelitian ini adalah Rancangan Acak Kelompok (RAK) yang terdiri dari 2 faktor yaitu blanching \& karagenan, 6 kombinasi perlakuan dengan 3 kali ulangan. Faktor pertama yaitu blanching, $(\mathrm{B} 1)=$ blanching, $(\mathrm{B} 2)=$ Tanpa blanching. Faktor kedua yaitu konsentrasi karagenan, $(\mathrm{K} 1)=5 \%$. K2 $=10 \%$. $\mathrm{K} 3=15 \%$.. Dengan kombinasi perlakuan yau B1K1: Blanching dan karagenan 5\% B1K2: Blanching dan karagenan 10\% B1K3: Blanching dan karagenan 15\% B2K1: Tanpa blanching dan karagenan 5\% B2K2: Tanpa blanching dan karagenan 10\% B2K3: Tanpa blanching dan karagenan $15 \%$

\section{Tahapan penelitian}

Tahap pelaksanaan meliputi sortasi, pencucian, pengupasan, pemotongan, perebusan, penghancuran, pemasakan, pendinginan dan pengemasan. Sortasi merupakan tahan awal yang dilakukan untuk memilih buah belimbing wuluh yang bagus, tanpa ada yang cacat, buahnya tidak terlalu masak dan tidak terlalu muda. Dilanjutkan pencucian dengan air yang mengalir sehingga menghilangkan kotoran. Belimbing wuluh dipotong menjadi bagian-bagian kecil dan biji belimbing wuluh dipisah dari dagingnya. Belimbing wuluh diberi perlakuan tanpa blanching dan blancing. Proses blanching dengan perebusan daging buah pada suhu $70^{\circ} \mathrm{C}-80^{\circ} \mathrm{C}$ sekitar 5 menit. Selanjutanya dilakukan penghancuran buah belimbing wuluh menggunakan blender menghasilkan bubur buah. Bubur belimbing wuluh di dipanaskan bersama bahan baku lain yaitu gula pasir, glukosa, agar-agar dan karagenan (konsentrasi 5\%, 10\%, 15\%.) selama 25 menit dengan suhu $80^{\circ} \mathrm{C}$. Selama proses pemasakan dilakukan pengadukan secara terus menerus dan suhu dipertahankan konstan. Proses pemasakan dihentikan hingga membentuk gel. Dilanjutkan proses pendinginan, pencetakan dan proses pengemasan dalam aluminium foil.

\section{Pengamatan}

Pengamatan yang akan dilakukan meliputi uji fisikokimia dan organoleptik. Analisa fisikokimia meliputi kadar kadar air (AOAC, 1990), vitamin C metode Iodometri (Sudarmaji et al., 1997) tekstur (daya patah) dan warna metode L, a, b Hunter (Yuwono et al., 1998). Sedangkan sifat organoleptik meliputi kesukaan warna, rasa, tekstur dan aroma (hedonic) menggunakan 30 orang panelis dari kategori tidak terlatih.

\section{Analisis data}

Analisa data fisikokimia dilakukan secara anova menggunakan software Minitab 18 dengan selang kepercayaan 5\%. Apabila ditemukan pengaruh nyata terhadap salah satu variabel maka dilanjutkan dengan uji Tukey Untuk uji-organoleptik menggunakan uji Friedman. Penentuan perlakuan terbaik fisikokimia dan organoleptik menggunakan metode Indeks Efektifitas De Garmo. et al., (1984) yang dimodifikasi oleh (Susrini, 2003).

\section{HASIL DAN PEMBAHASAN}

\section{Kadar air}

Berdasarkan hasil penelitian menunjukkan bahwa rata-rata kadar air pada selai lembaran belimbing wuluh dengan perbedaan penambahan karagenan dan proses blanching berkisar antara 18,75 25,64\%. Kadar

Kadar air tertinggi diperoleh pada perlakuan B1K3 yaitu 25,64\% dan terendah pada perlakuan B2K3 (Tanpa blanching \& karagenan 15\%) yaitu $18,75 \%$. Hasil analisis ragam menunjukkan bahwa perlakuan penambahan karagenan dan proses blanching yang menunjukkan perbedaan yang nyata pada taraf 5\%. Data hasil analisis kadar air disajikan pada Tabel 1. 
Tabel 1. Rata-rata kadar air $(\%)$

\begin{tabular}{lc}
\hline \multicolumn{1}{c}{ Perlakuan } & Kadar Air (\%) \\
\hline B1K1 (blanching \& karagenan 15\%) & $25,64 \mathrm{a}$ \\
B1K2 (blanching \& karagenan 5\%) & $22,91 \mathrm{~b}$ \\
B1K2 (blanching \& karagenan 10\%) & $21,10 \mathrm{c}$ \\
B2K1 (tanpa blanching \& karagenan 5\%) & $19,72 \mathrm{~d}$ \\
B2K2 (tanpa blanching \& karagenan 10\%) & $19,68 \mathrm{~d}$ \\
B2K3 (tanpa blanching \& karagenan 15\%) & $18,75 \mathrm{e}$ \\
\hline
\end{tabular}

Keterangan: Notasi yang berbeda dalam setiap perlakuan menunjukkan berbeda nyata pada uji Tukey.

Semakin tinggi konsentrasi karagenan maka semakin rendah kadar air selai lembaran belimbing wuluh. Hal ini disebabkan semakin banyak konsentrasi karagenan di dalam bahan maka jumlah padatan akan semakin banyak yang yang terikat dan kadar air bahan akan menurun. Menurut Mawarni (2019) karagenan bersifat hidrokoloid yang dapat mempertahankan air dalam bahan pangan. Peningkatan hidrokoloid menyebabkan air yang terikat dalam jaringan hidrokoloid semakin besar. Air yang terukur sebagai kadar air adalah air bebas dan air teradsorbsi, di mana air teradsorbsi ini merupakan air yang terikat dalam jaringan hidrokoloid

Menurut Harun et al.., (2016) karagenan juga memiliki ion bebas $\mathrm{OH}-$ yang mampu berikatan dengan air sehingga ikatan menjadi lebih kuat, sehingga semakin tinggi konsentrasi karagenan yang digunakan maka kadar air selai lembaran akan semakin menurun. Pada saat proses blanching menyebabkan kandungan pektin pada belimbing wuluh menjadi larut dan berikatan dengan air, sehingga pektin akan menggumpal dan membentuk suatu serabut halus dan bersifat kenyal, pada saat proses pemasakan makin sedikit air yang dapat dilepaskan sehingga teksturnya semakin lunak (Fajarwati, 2017).

\section{Vitamin C}

Berdasarkan hasil penelitian menunjukkan bahwa rata-rata vitamin $\mathrm{C}$ pada selai lembaran belimbing wuluh dengan perbedaan penambahan karagenan dan proses blanching berkisar antara 8,62-14,51 $\mathrm{mg} / \mathrm{g}$. Kadar vitamin $\mathrm{C}$ tertinggi diperoleh pada perlakuan B2K2 yaitu $14,51 \mathrm{mg} / \mathrm{g}$ dan terendah pada perlakuan B1K1 yaitu 8,62 $\mathrm{mg} / \mathrm{g}$. Hasil analisis ragam menunjukkan bahwa perlakuan penambahan karagenan dan proses blanching tidak memberikan perbedaan nyata terhadap vitamin C. Data hasil analisis vitamin $\mathrm{C}$ dapat dilihat pada Tabel 2.

Hasil penelitian Haryu (2016) menyatakan karagenan memiliki sifat sangat mudah mengikat molekul-molekul air dan senyawa-senyawa lain seperti vitamin $C$, asam-asam organik, yang terdapat di dalam campuran, sehingga senyawa yang mudah menguap dan rusak oleh proses pengolahan dapat dihambat sebagian dengan penambahan karagenan. Konsentrasi karagenan yang tinggi mampu membentuk disperse koloid (struktur double helix) lebih banyak dan kuat sehingga akan menghambat oksidasi vitamin $\mathrm{C}$ sehingga mempertahankan vitamin C. Struktur double helix yang tinggi menyebabkan kareganan mampu melindungi vitamin $\mathrm{C}$ dengan matriksnya yang kuat ini sehingga terlindung dari kerusakan akibat pemanasan. 
Tabel 2. Rata-rata vitamin $\mathrm{C} \mathrm{mg/g}$

\begin{tabular}{lc}
\hline \multicolumn{1}{c}{ Perlakuan } & Vitamin C ( mg/g) \\
\hline B1K1 (blanching \& karagenan 15\%) & $8,62 \mathrm{a}$ \\
B1K2 (blanching \& karagenan 5\%) & $10,10 \mathrm{a}$ \\
B1K2 (blanching \& karagenan 10\%) & $11,54 \mathrm{a}$ \\
B2K1 (tanpa blanching \& karagenan 5\%) & $11,59 \mathrm{a}$ \\
B2K2 (tanpa blanching \& karagenan 10\%) & $13,51 \mathrm{a}$ \\
B2K3 (tanpa blanching \& karagenan 15\%) & $11,68 \mathrm{a}$ \\
\hline
\end{tabular}

Keterangan: Notasi yang berbeda dalam setiap perlakuan menunjukkan berbeda nyata pada uji Tukey.

\section{Tekstur}

Hasil penelitian menunjukkan bahwa rata-rata tekstur pada selai lembaran belimbing wuluh dengan perbedaan penambahan karagenan dan proses blanching berkisar antara $0,20-2,10 \mathrm{~N} / \mathrm{mm}^{2}$. Perlakuan B2K1 (tanpa blanching \& karagenan 5\%) memiliki daya potong yaitu $2,10 \mathrm{~N} / \mathrm{mm}^{2}$ dan

Tabel 3. Rata-rata tekstur (N/mm $\left.{ }^{2}\right)$ perlakuan B2K3 (tanpa blanching \& karagenan $15 \%$ ) yaitu $0,20 \mathrm{~N} / \mathrm{mm}^{2}$. Hasil analisis ragam menunjukkan bahwa perlakuan penambahan karagenan dan proses blanching yang menunjukkan perbedaan yang nyata pada taraf $5 \%$. Data hasil analisis tekstur $\left(\mathrm{N} / \mathrm{mm}^{2}\right)$ dapat dilihat pada Tabel 3.

\begin{tabular}{lc}
\hline \multicolumn{1}{c}{ Perlakuan } & Tekstur $\left(\mathbf{N} / \mathbf{m m}^{2}\right)$ \\
\hline B1K1 (blanching \& karagenan 15\%) & $2,10 \mathrm{a}$ \\
B1K2 (blanching \& karagenan 5\%) & $1,50 \mathrm{~b}$ \\
B1K2 (blanching \& karagenan 10\%) & $0,80 \mathrm{c}$ \\
B2K1 (tanpa blanching \& karagenan 5\%) & $0,60 \mathrm{~cd}$ \\
B2K2 (tanpa blanching \& karagenan 10\%) & $0,50 \mathrm{~cd}$ \\
B2K3 (tanpa blanching \& karagenan 15\%) & $0,20 \mathrm{~d}$ \\
\hline
\end{tabular}

Keterangan: Notasi yang berbeda dalam setiap perlakuan menunjukkan berbeda nyata pada uji Tukey.

Semakin tinggi konsentrasi karagenan yang ditambahkan maka nilai tekstur keras yang menunjukkan tekstur lembaran selai semakin padat. Hal ini dikarenakan karagenan berfungsi sebagai penstabil yang mampu mengikat air, namun jika karagenan ditambahkan bertambah banyak maka tekstur produk cenderung menjadi keras (Zulkipli, 2017). Hal ini sesuai dengan penelitian Dewi (2018) bahwa semakin tinggi penambahan karagenan dan sukrosa yang digunakan maka tekstur selai jambu biji merah yang dihasilkan akan semakin keras. Hal ini disebabkan karena karagenan yang digunakan pada penelitian ini yaitu jenis kappa karagenan yang dapat menghasilkan gel yang kuat (rigid). sehingga semakin tinggi konsentrasi karagenan yang diberikan pada setiap perlakuan maka akan menghasilkan tekstur selai semakin keras. Hal ini dikarenakan sukrosa bersifat higroskopis atau mengikat air sehingga penambahan sukrosa menyebabkan terikatnya sebagian air dari bahan yang menyebabkan jumlah air bebas berkurang sehingga tekstur menjadi semakin keras.

\section{Warna $\left(\mathbf{L}, \mathbf{a}^{*}, \mathbf{b}^{*}\right)$}

Rerata data hasil analisis warna selai lembaran belimbing wuluh disajikan pada Tabel 4. Berdasarkan hasil penelitian menunjukkan bahwa rata-rata warna $\mathrm{L}$ (tingkat kecerahan) berkisar antara $(34,60$ $37,70)$, nilai $a^{*}$ berkisar antara $(11,30$ $14,20)$, nilai $b^{*}$ berkisar antara $(20,20-$ 31,80). Semakin banyak penambahan karagenan dan proses blanching maka akan dapat menurunkan tingkat kecerahan selai lembaran belimbing wuluh. Hal ini dikarenakan terjadi reaksi pencokelatan non enzimatis berupa reaksi maillard pada proses pemasakan. Selain itu produk selai lembaran 
ini mengandung vitamin $\mathrm{C}$ sehingga terjadi reaksi pencokelatan karena degradasi asam askorbat yang mengakibatkan warna selai lembaran akan lebih gelap (Mawarni, 2019). Menurut Imaduddin (2017) hal ini diduga karena semakin banyak molekul air yang terperangkap dalam struktur gel, maka ikatan antar pembentuk gel yaitu gula dan karagenan dengan air akan semakin rapat sehingga warna yang dihasilkan cenderung lebih gelap.

Semakin tinggi konsentrasi karagenan maka rata rata warna $a^{*}$ semakin rendah, maka berwarna kuning kehijauan. Terjadinya penurunan nilai warna disebabkan oleh kekentalan produk yang semakin meningkat. Belimbing wuluh mengandung zat pigmen klorofil. Warna hijau pada belimbing wuluh sebagaimana pada buah dan sayuran lainnya berhubungan dengan kandungan pigmen hijau daun yang disebut dengan klorofil (Prasetya, 2019).

Semakin tinggi konsentrasi karagenan menunjukkan penurunan pada rata-rata nilai b*. Terjadinya penurunan nilai warna disebabkan oleh perubahan warna kuning yang terdapat pada selai lembaran belimbing wuluh juga diakibatkan karena kandungan kadar air pada belimbing wuluh sehingga dapat menurunkan intensitas warna kekuningan, dan akan mengalami perubahan warna menjadi putih kekuningan (Prasetya, 2019).

Tabel 4. Rata-rata kadar warna

\begin{tabular}{lccc}
\hline \multicolumn{1}{c}{ Perlakuan } & L & a* & b $^{*}$ \\
\hline B1K1 (blanching \& karagenan 15\%) & $37,70 \mathrm{a}$ & $13,80 \mathrm{ab}$ & $31,80 \mathrm{a}$ \\
B1K2 (blanching \& karagenan 5\%) & $36,80 \mathrm{ab}$ & $11,40 \mathrm{c}$ & $20,20 \mathrm{e}$ \\
B1K2 (blanching \& karagenan 10\%) & $34,60 \mathrm{~d}$ & $11,30 \mathrm{c}$ & $22,70 \mathrm{c}$ \\
B2K1 (tanpa blanching \& karagenan 5\%) & $36,40 \mathrm{bc}$ & $14,20 \mathrm{a}$ & $28,10 \mathrm{~b}$ \\
B2K2 (tanpa blanching \& karagenan 10\%) & $35,50 \mathrm{~cd}$ & $13,20 \mathrm{~b}$ & $20,80 \mathrm{de}$ \\
B2K3 (tanpa blanching \& karagenan 15\%) & 36,80ab & $11,60 \mathrm{c}$ & $21,70 \mathrm{~cd}$ \\
\hline
\end{tabular}

Keterangan: Notasi yang berbeda dalam setiap perlakuan menunjukkan berbeda nyata pada uji Tukey.

\section{Uji organoleptik}

Pengujian organoleptik dilakukan berdasarkan tingkat kesukaan terhadap selai lembaran belimbing wuluh yang meliputi tekstur, warna, rasa, dan aroma. Panelis yang digunakan panelis tidak terlatih dengan jumlah 30 panelis. Skala kesukaan yang digunakan mulai dari skor 1 (sangat tidak suka) sampai 5 (amat sangat suka).

\section{Tekstur}

Hasil uji organoleptik menunjukkan bahwa rata-rata kesukaan terhadap tekstur selai lembaran belimbing wuluh berkisar antara 2,40-3,73 (sangat tidak suka-amat sangat suka). Hasil uji organoleptik terhadap tekstur selai lembaran belimbing wuluh dapat dilihat pada Gambar 1.

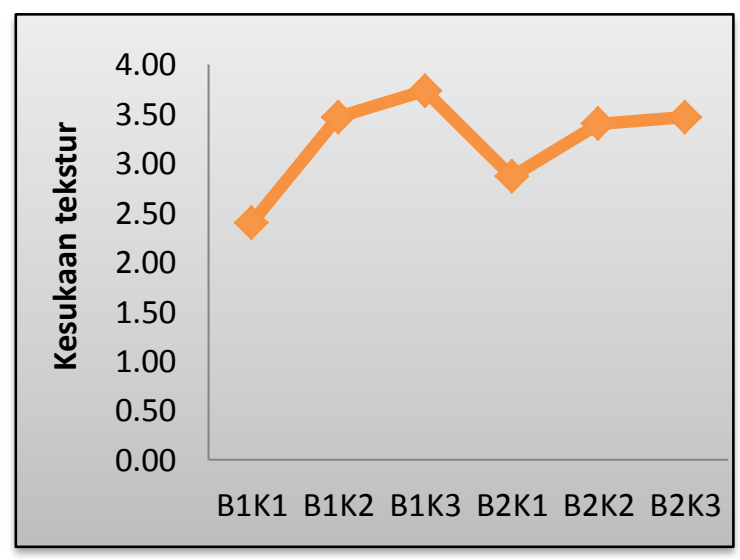

Gambar 1. Nilai kesukaan terhadap tekstur

Dari hasil tersebut dapat dinyatakan bahwa semakin banyak karagenan yang ditambahkan akan menyebabkan tekstur semakin keras karena kemampuan karagenan dalam membentuk gel sangat kuat, sedangkan lama pemasakan yang semakin lama juga akan membuat tekstur selai semakin keras karena dengan pemanasan 
akan membuat air yang ada pada selai akan menguap sehingga membuat tekstur selai semakin keras. Sedangkan bila semakin rendah lama pemasakan dan konsentrasi karagenan maka tekstur selai lembaran akan semakin lembek sehingga membuat panelis kuras menyukai dan lebih menyukai selai tekstur yang lebih kokoh (Mawarni, 2019).

\section{Warna}

Hasil uji organoleptik menunjukkan bahwa rata-rata kesukaan terhadap warna selai lembaran belimbing wuluh berkisar antara 2,97-3,50 (tidak suka-amat sangat suka). Hasil uji organoleptik terhadap tekstur selai lembaran belimbing wuluh dapat dilihat pada Gambar 2.

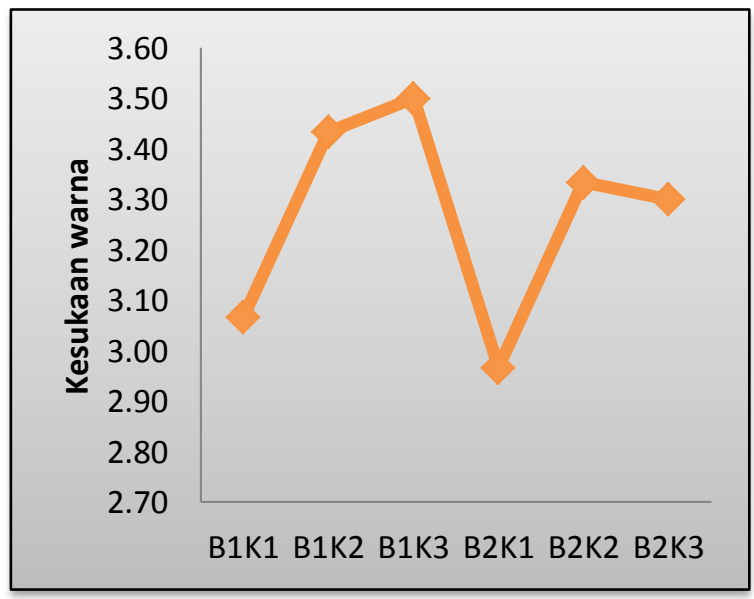

Gambar 2. Nilai kesukaan terhadap warna

Dari hasil tersebut dapat dinyatakan bahwa. Dari hasil tersebut dapat dinyatakan bahwa panelis sangat menyukai warna selai lembaran dengan perlakuan B1K3 (blanching \& karagenan 15\%). Pada perlakuan tersebut warna selai lembaran belimbing wuluh hijau pekat (gelap). Dengan semakin bertambahnya karagenan, warna hijau terlihat semakin gelap. Hal ini sesuai dengan pendapat Khamidah, (2017). bahwa karagenan dapat larut dalam air, membentuk larutan kental, sehingga dapat mempengaruhi warna produk.

\section{Rasa}

Hasil uji organoleptik menunjukkan bahwa rata-rata kesukaan terhadap rasa selai lembaran belimbing wuluh berkisar antara 2,90-3,57 (tidak suka-amat sangat suka). Hasil uji organoleptik terhadap tekstur selai lembaran belimbing wuluh dapat dilihat pada Gambar 3.

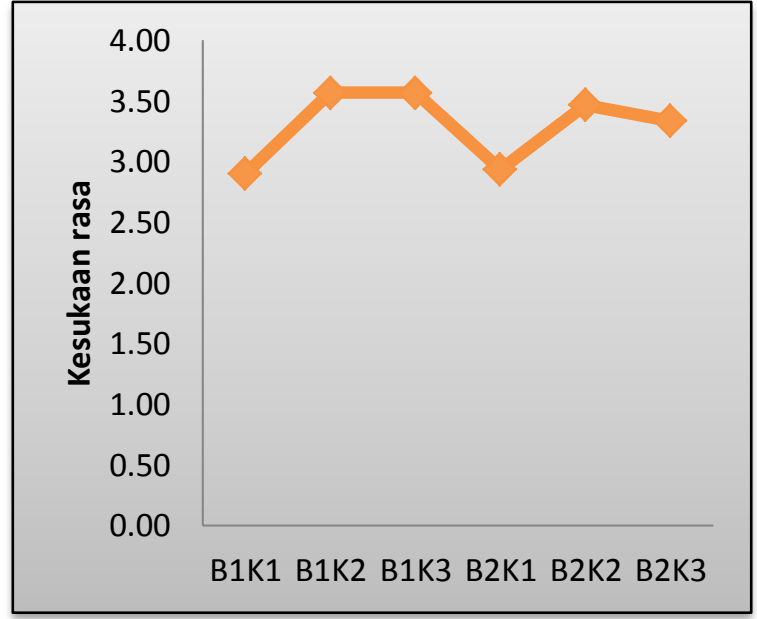

Gambar 3. Nilai kesukaan terhadap rasa

Dari hasil tersebut dapat dinyatakan bahwa panelis menyukai pada dua perlakuan, proporsi bahan yang sama pada tiap perlakuan tersebut diduga menyebabkan rasa pada selai lembaran kurang lebih sama. Faktor yang digunakan pada pembuatan selai yaitu penambahan karagenan dan lama pemasakan, di mana karagenan memberikan pengaruh netral terhadap rasa, karena karagenan tidak memiliki rasa. Karagenan memiliki sifat larut dalam air panas dan akan membentuk gel pada suhu $45^{\circ} \mathrm{C}$ dan $65^{\circ} \mathrm{C}$, stabil terhadap $\mathrm{pH}$ netral dan asam, dan kuat dalam pembentukan gel (Mawarni, 2019).

\section{Aroma}

Hasil uji organoleptik menunjukkan bahwa rata-rata kesukaan terhadap aroma selai lembaran belimbing wuluh berkisar antara 3,07-3,47 (tidak suka-amat sangat suka). Hasil uji organoleptik terhadap tekstur selai lembaran belimbing wuluh dapat dilihat pada Gambar 4. 


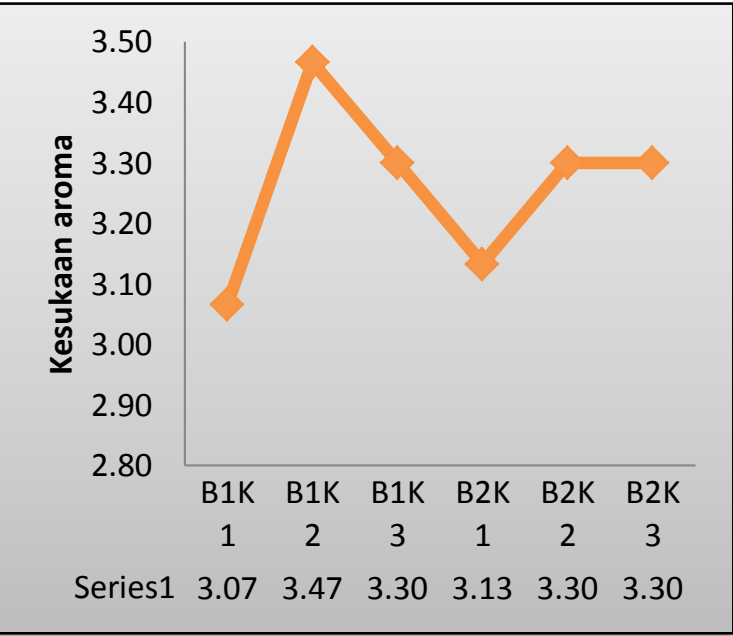

Gambar 4. Nilai kesukaan terhadap aroma

Aroma pada selai lembaran kurang lebih sama. Faktor yang digunakan pada pembuatan selai yaitu penambahan karagenan dan lama pemasakan, di mana karagenan memiliki aroma yang cenderung hambar sehingga tidak mempengaruhi aroma selai lembaran (Mawarni, 2019).

\section{KESIMPULAN}

Berdasarkan hasil penelitian dan pembahasan yang ada dapat disimpulkan sebagai berikut:

1. Perlakuan proses blanching dan penambahan karagenan berpengaruh nyata terhadap kadar air, tekstur, dan warnaselai lembaran belimbing wuluh (Averrhoa bilimbi Linn.). Namun perlakuan blanching dan penambahan karagenan tidak berpengaruh nyata terhadap kadar vitamin $\mathrm{C}$ selai lembaran belimbing wuluh..

2. Perlakuan proses blanching dan penambahan karagenan berpengaruh nyata terhadap organoleptik kesukaan tekstur, warna, rasa dan aroma dari selai lembaran belimbing wuluh.

3. Hasil perhitungan menunjukkan perlakuan terbaik terdapat pada perlakuan B2K2 dengan perlakuan penambahan karagenan $10 \%$ dengan tanpa blanching. Dengan hasil kadar air 19,68\%; vitamin C 14,51 mg/g; Tekstur $0,50 \mathrm{~N} / \mathrm{mm}^{2}$; warna kecerahan (L) 35,50 warna kemerahan $\left(\mathrm{a}^{*}\right)$ 13,20; warna kekuningan $\quad\left(b^{*}\right) \quad 20,80 ; \quad$ tekstur (organoleptik) 3,40 (suka); warna 3,33 (suka); rasa 3,47 (suka) dan aroma 3,30 (suka).

\section{SARAN}

Dalam penelitian tersebut perlu ada penelitian lanjutan tentang suhu dan waktu yang optimal dalam pembuatan selai lembaran belimbing wuluh dan tentang waktu daya simpan dari produk tersebut.

\section{DAFTAR PUSTAKA}

Anuar, N. A., \& Salleh, R. M. (2019). Development of fruit jam from Averrhoa bilimbi L. Journal of Food Processing and Preservation,43(4), 13904.

AOAC. (1990). Official methods of analysis of association of official analytical chemist. Association of Official Agricultural Chemists.

Dewi, E. N., Surti, T., \& Ulfatun, U. (2010). Kualitas Selai yang Diolah dari Rumput Laut, Gracilaria Verrucosa, Eucheuma Cottonii, serta Campuran Keduanya. Jurnal Perikanan Universitas Gadjah Mada,12(1), 2027. https://doi.org/10.22146/jfs.2904

Dewi, N. W. V. S. (2018). Pengaruh konsentrasi karagenan dan sukrosa terhadap sifat fisik, kimiadan organoleptik selai jambu biji merah (Psidium guajava L.) [Disertasi]. Universitas Mataram.

Fajarwati, N. H., Parnanto, N. H. R., \& Manuhara, G. J. (2017). Pengaruh konsentrasi asam sitrat dan suhu pengeringan terhadap karakteristik fisik, kimia dan sensoris manisan kering labu siam (Sechium edule Sw.) Dengan pemanfaatan pewarna alami dari ekstrak rosela ungu (Hibiscus sabdariffa L.). Jurnal Teknologi Hasil Pertanian, 10(1), 50-66. https://doi.org/10.20961/jthp.v10i1.174 94

Fatonah, W. (2002). Optimasi selai dengan 
bahan baku ubi jalar cilembu [Tugas Akhir]. Institut Pertanian Bogor.

Harun, N. (2016). Pemanfaatan karagenan dalam pembuatan selai lembaran labu Kuning (Cucurbita moschata). Jurnal Online Mahasiswa Fakultas Pertanian Universitas Riau, 3(2), 1-8.

Haryu, A. S. P., Parnanto, N. H. R., \& Nursiwi, A. (2016). Pengaruh penambahan karagenan terhadap karakteristik fisik, kimia dan sensoris fruit and vegetable leather berbasis albeno semangka (Citrullus vulgaris schard.) dan labu siam (Sechium edule). Jurnal Teknosains Pangan, 5(3).

Ikram, E. H. K., Eng, K. H., Jalil, A. M. M., Ismail, A., Idris, S., Azlan, A., \& Mokhtar, R. A. M. (2009). Antioxidant capacity and total phe- nolic content of Malaysian underutilized fruits. Journal of Food Composition and Analysis, $22(5)$ 388-393. https://doi.org/10.1016/j.jfca.2009.04.0 01

Imaduddin, A. H., \& Susanto, W. H. (2017). Pengaruh tingkat kematangan buah belimbing (Averrhoa carambola L.) dan Proporsi penambahan gula terhadap karakteristik fisikokimia dan organoleptik lempok belimbing. Jurnal Pangan dan Agroindustri, 5(2), 45-57.

Ismail, A., Idris, S., Azlan, A., \& Mokhtar, R. A. M. (2009). Antioxidant capacity and total phe- nolic content of Malaysian underutilized fruits. Journal of Food Composition and Analysis, $22(5)$ 388-393. https://doi.org/10.1016/j.jfca.2009.04.0 01

Kanwal, N., Randhawa, M. A., \& Iqbal, Z. (2017). Influence of processing methods and storage on physicochemical and antioxidant properties of guava jam. International Food Research Journal, 24(5), 2017-2027.

Khamidah, A. (2017). Pemanfaatan sawi dalam pembuatan permen jelly untuk meningkatkan nilai tambah. Research Report, 1193-1201.
M. Yusuf, A, Rokhani, H., \& Usman, A. (2016). Dosis blansir untuk memperpanjang umur simpan daging buah kelapa kopyor. Repositori Publikasi Kementerian Pertanian Republik Indonesia.

Masilungan, G. D., \& Absulio, W. L. (2012). Fruits of bilimbi (Averrhoa bilimbi L.) as a new natural source of ethylene for ripening of "Saba" banana (Musa balbisiana BBB). Philipp Agric Scientist, 95(4), 406-410.

Mawarni, S. A., dan Yuwono, S. S. (2019). Pengaruh lama pemasakan dan konsentrasi karagenan terhadap sifat fisik, kimia dan organoleptik selai lembaran mix fruit (belimbing dan apel). Jurnal Pangan dan Agroindustri, 6(2), 33-41. http://dx.doi.org/10.21776/ub.jpa.2018. 006.02.4

Prasetya, D. A., \& Evanuarini, H. (2019). Kualitas mayonnaise menggunakan sari belimbing wuluh (Averrhoa bilimbi L.) sebagai pengasam ditinjau dari kestabilan emulsi, droplet emulsi dan warna. Jurnal Ilmu dan Teknologi Hasil Ternak (JITEK), 14(1), 20-29. https://doi.org/10.21776/ub.jitek.2019. 014.01 .3

Prastian, E. (2008). Uji efek etanol 70\% buah belimbing wuluh (averrhoa blimbi) terhadap penurunan kadar kolesterol [Tugas Akhir]. Universitas Muhammadiyah Surakarta.

Sidi, N. C., Widowati, E., \& Nursiwi, A. (2014). Pengaruh Penambahan Karagenan pada Karakteristik Fisikokimia dan Sensoris Fruit Leather Nanas (Ananas Comosus L. Merr.) dan Wortel (Daucus Carota). Jurnal Aplikasi Teknologi Pangan, 3(4), 122127.

Sudarmadji, Slamet, Haryono, Bambang, \& Suhardi. (1997). Prosedur analisis untuk bahan makanan dan pertanian. Yogyakarta: Liberty.

Susrini. (2003). Indeks efektifitas. Universitas Brawijaya.

Yuwono, S., \& Susanto, T. (1998). 
Pengujian fisik pangan. Universitas Brawijaya.

Zulkipli, F. M. P. (2017). Penambahan konsentrasi bahan penstabil dan gula terhadap karakteristik fruit leather murbei (Morus nigra) [Disertasi]. Universitas Pasundan. 